\title{
SEVERE HYPERTENSION ASSOCIATED WITH PANCURONIUM IN A PATIENT WITH A PHAEOCHROMOCYTOMA
}

\author{
Ronald M. Jones ANd ANNe B. Hill
}

\begin{abstract}
Agstract
There are a number of factors to consider in choosing a muscle relaxant for patients with a phaeochromocytoma. It has been suggested that pancuronium is the muscle relaxant of choice. ${ }^{1-3}$ This report describes a severe hypertensive response associated with pancuronium in a patient undergoing surgery for the removal of a phaeochromocytoma.
\end{abstract}

Key Words: PhaEOChromocytoma, pancuronium, hypertensive crisis.

\section{CASE REPORT}

A $53-$ YEAR-OLD WHITE FEMALE weighing $66 \mathrm{~kg}$ was admitted to the hospital with a six month history of hypertension associated with paroxysmal attacks of severe bifrontal headache, nausea, chest pain and anxiety. Her blood pressure between attacks was $21.3 / 11.9 \mathrm{kPa}(160 / 90 \mathrm{~mm} \mathrm{Hg})$, but during an attack was often in excess of 29.3/ $16.0 \mathrm{kPa}(220 / 120 \mathrm{~mm} \mathrm{Hg})$. On admission to hospital her medication consisted of metoprolol $100 \mathrm{mg}$ three times a day. Urine analysis indicated a norepinephrine excretion of $203 \mu \mathrm{g} / 24$ hours (normal up to $100 \mu \mathrm{g} / 24$ hours), epinephrine excretion of $137 \mu \mathrm{g} / 24$ hours (normal up to $20 \mu \mathrm{g} /$ 24 hours) and a urinary vanillyl mandelic acid of 14 $\mathrm{mg} / 24$ hours (normal up to $7 \mathrm{mg} / 24$ hours). The diagnosis of phaeochromocytoma was supported by an upper abdominal computerized tomography scan which showed an $8.0 \mathrm{~cm}$ spherical mass superior and anterior to the left upper renal pole, consistent with a phaeochromocytoma. The patient also exhibited a diabetic type glucose tolerance test thought to be secondary to the tumour. In 1970 she had suffered a subarachnoid haemorrhage after rupture of a berry aneurysm at the bifurcation of the left internal carotid artery and circle of Willis. At that time she had undergone left internal carotid artery ligation and clipping of the aneurysm and she had a residual third cranial nerve paralysis with an unreactive

Ronald M. Jones, M.B., F.F.A.R.C.S.* Instructor in Anesthesiology; Anne B. Hill, M.D., Assistant Professor of Anesthesiology, University of Michigan Medical Center, Ann Arbor, Michigan 48109.

*Present address: Department of Anaesthesia, University Hospital, Queen's Medical Centre, Nottingham, England, NG7 2UH.

Canad. Anaesth. Soc. J., vol. 28, no. 4, July 1981 dilated left pupil. One wcek before the operation she was started on phenoxybenzamine $120 \mathrm{mg}$ daily to achieve alpha adrenergic receptor blockade. During her admission to the hospital, before the operation, the patient had not suffered any hypertensive crises.

Pre-anaesthetic medication consisted of morphine sulphate $6 \mathrm{mg}$ intramuscularly and diazepam $10 \mathrm{mg}$ orally, 90 minutes before arrival in the operating room. The patient was well sedated but responded to command and her blood pressure was $14.6 / 8.0 \mathrm{kPa}(110 / 60 \mathrm{~mm} \mathrm{Hg})$. She was given $50 \mu \mathrm{g}$ of fentanyl and $2.5 \mathrm{mg}$ of droperidol before the insertion of a 20 gauge non-tapered Teflon cannula (Abbocath) in the left radial artery, which was used to monitor blood pressure continuously during induction of anaesthesia. No elevation of blood pressure or subjective feelings of discomfort occurred during placement of the arterial cannula. After five minutes of preoxygenation, the patient was given a further $50 \mu \mathrm{g}$ of fentanyl, $2.5 \mathrm{mg}$ of droperidol and $100 \mathrm{mg}$ of thiamylal. Anaesthesia was maintained with nitrous oxide and 40 per cent oxygen with two to three per cent enflurane, the patient continuing to breath spontaneously. After seven minutes, during which time the blood pressure and heart rate remained stable at $14.6 / 8.0 \mathrm{kPa}(110 / 60 \mathrm{~mm} \mathrm{Hg})$ and 76 beats per minute, respectively, pancuronium was injected, and ventilation was gently assisted. To facilitate smooth tracheal intubation, without coughing or bucking, which is known to cause catecholamine release, ${ }^{2}$ a dose of $0.15 \mathrm{mg} \cdot \mathrm{kg}^{-1}(10 \mathrm{mg})$ of pancuronium was administered. About 90 seconds after injecting the pancuronium the blood pressure rose suddenly to $30.6 / 17.3 \mathrm{kPa}(230 / 130 \mathrm{~mm} \mathrm{Hg})$ and heart rate increased to 120 beats per minute. No 
anaesthetic or surgical stimulus had been applied at this time and, before this, induction had been smooth without breath-holding, coughing or periods of apnoea. The patient had not been moved nor had laryngoscopy been attempted. Phentolamine was given in $1.0 \mathrm{mg}$ increments intravenously and, after a total of $8 \mathrm{mg}$ had been injected over three minutes, the blood pressure was $18.6 / 12.0 \mathrm{kPa}(140 / 90 \mathrm{~mm} \mathrm{Hg})$ and heart rate 86 beats per minute. Propranolol $1.0 \mathrm{mg}$ was then given intravenously and a further $450 \mu \mathrm{g}$ of fentanyl was given slowly to ensure cardiovascular stability during laryngoscopy. Initial laryngoscopy and spraying of the larynx with topical analgesia was uneventful and three minutes later the trachea was intubated without change in pulse rate or blood pressure. The patient remained stable until surgical manipulation of the tumour commenced, which caused a rise in blood pressure to $23.9 / 13.3 \mathrm{kPa}(180 / 100 \mathrm{~mm} \mathrm{Hg})$ which responded promptly to a further $3.0 \mathrm{mg}$ of phentolamine. Removal of the tumour coincided with the loss of two litres of blood because of the proximity of the tumour capsule to the spleen and splenic vein. This resulted in a brief period of hypotension (B.P. $12 / 8 \mathrm{kPa}(90 / 60 \mathrm{~mm} \mathrm{Hg})$ ) which responded to rapid blood transfusion. The patient made an uneventful recovery from anaesthesia and surgery.

\section{Discussion}

Arterial hypertension and cardiac arrhythmias commonly occur during operation for removal of a phaeochromocytoma, due to release into the circulation of adrenaline and noradrenaline. This is most likely to occur during tracheal intubation, when moving the patient and during manipulation of the tumour. ${ }^{2}$ Any anaesthetic, surgical, or pharmacological stimulus to catecholamine release must be avoided. Preoperative treatment with alpha and beta receptor blocking drugs and the use of anaesthetic agents which promote cardiovascular stability have greatly decreased the mortality of patients undergoing removal of a phaeochromocytoma from $30-45$ per cent ${ }^{4}$ in the early 1950's to less than 5 per cent in a recent review. ${ }^{5}$

Various recommendations, based on theoretical and practical considerations, have been made regarding the muscle relaxant most suitable for these patients. Succinylcholine is relatively contraindicated because of its ability to stimulate sympathetic ganglia and elevate arterial pressure ${ }^{2}$ indeed there is a report of a sudden rise in blood pressure associated with the muscle fasiculations which accompany succinylcholine administration. ${ }^{6}$ Gallamine is also contraindicated because of its ability to release catecholamines and tendency to cause tachycardia. ${ }^{2}$ Curare has been recommended, ${ }^{7}$ but others feel the histamine release caused by curare may lead to catecholamine release and hypertension. ${ }^{2.8}$ Pancuronium very rarely causes histamine release and does not block sympathetic ganglia, ${ }^{9}$ and for these reasons has been advocated as the relaxant of choice. ${ }^{1,2,3}$ However, pancuronium has been shown to cause release of catecholamines at adrenergic nerve endings ${ }^{10}$ and increased blood catecholamine levels have been recorded after its administration." In the case described, we believe that the extreme hypertension and tachycardia secondary to the administration of pancuronium was caused by catecholamine release. The hypertension quickly responded to the administration of phentolamine, a short acting $\alpha$-adrenergic blocking agent. Preoperative $\alpha$ adrenergic blockade was introduced in 1962 by Johns and Brunjes, ${ }^{12}$ but complete $\alpha$-adrenergic blockade has a number of undesirable effects. These include pre-operative postural syncope, and an increased difficulty in controlling the profound hypotension which sometimes occurs after tumour removal. Additionally a rise in blood pressure on tumour palpation is a useful sign when searching for small tumours or metastases. For these reasons partial $\alpha$-adrenergic blockade has been recommended ${ }^{13}$ with the purpose of blunting, not ablating, the cardiovascular effects of catecholamine release. In the case described, however, the extent of the cardiovascular response to the administration of pancuronium, may indicate an insufficient degree of preoperative $\alpha$-adrenergic blockade.

The use of droperidol during induction of anaesthesia in this patient also requires consideration. Droperidol has been recommended by previous authors ${ }^{2.14}$ as part of a neurolept anaesthetic technique for patients with a phaeochromocytoma. It is known to antagonize the pressor effects of catecholamines ${ }^{15}$ and prevent catecholamine-induced arrhythmias. ${ }^{16}$ There are, however, two clinical reports of hypertension induced by droperidol in patients with a phaeochromocytoma. ${ }^{17,18}$ The mechanism of this may be inhibition by droperidol of uptake of catecholamines into the nerve terminals. ${ }^{17}$ In both these reports the onset of hypertension and tachycardia was usually within three minutes and always within five minutes after droperidol administra- 
tion. The onset of hypertension and tachycardia following droperidol administration in the patient reported here was significantly longer than this. The likelihood of the hypertensive crisis being due to droperidol is therefore considered to be slight. Although this report does not indicate a certain association between pancuronium administration and extreme hypertension in a patient with a phaeochromocy toma the temporal association was striking and no other stimulus, anaesthetic, surgical or pharmacological had occurred in the preceding seven minutes. It is concluded that the administration of pancuronium may cause catecholamine release and initiate a severe hypertensive episode, and that this muscle relaxant should be used with caution in patients with a phaeochromocytoma.

\section{REFERENCES}

1. Janeczko, G.F., Ivankovich, A.D., Glisson, S.N., Heyman, H.J., El-Etr., A. A.\& Albrecht, R.F. Enflurane anaesthesia for surgical removal of pheochromocytoma. Anes. Analg. 56: 62 (1977).

2. Stamenkovic, L. \& Spierdijk, J. Anaesthesia in patients with phaeochromocytoma. Anaesthesia 31: 941 (1976).

3. James, M.L. Endocrine disease and anaesthesia. Anaesthesia 25: 232 (1970)

4. Apgar, V. \& Papper, E.M. Pheochromocytoma: anesthetic management during surgical treatment. Arch. Surg. 62: 634 (1951).

5. Remine, W.H., Chong, G.C., Van Heerden, J.A.. Sheps, S.G. \& Harrison, E.G. Current management of pheochromocytoma. Ann. Surg. 179: 740 (1974)

6. Crout, J.R. \& Brown, B.R. Anesthetic man- agement of pheochromocytoma: The value of phenoxybenzamine and methoxyflurane. Anesthesiology 30: 29 (1969).

7. MiLlaR, R.A. Pituitary and adrenal glands in relation to anaesthesia. In: General Anaesthesia, 4th ed. Edited by Gray, T.C., Nunn J.F., Utting, J.E. London, Butterworths, 1980, pp. 818-822.

8. Pratilas, V. \& Pratila, M.G. Management of Pheochromocytoma. Anesth. Rev. V1: 44 (1979).

9. Calvey, T.N. \& Wilson, H. Muscle relaxant drugs and their antagonists. In: General Anaesthesia, 4th ed. Edited by Gray, T.C., Nunn, J.F., Utting, J.E. London, Butterworths, 1980, pp. 328.

10. Domenech, J.S., Garcia, R.C., Rodriguez Sasiain, J.M., Loyola, A.Q. \& Oroz, J.S. Pancuronium bromide: an indirect sympathomimetic agent. Brit. J. Anaesth. 48: 1143 (1976).

11. Nana, A., Cardan, E. \& Domokos, M. Blood catecholamine changes after pancuronium. Acta anaesth. Scand. 17: 83 (1973).

12. JoHns, V.J. \& BRUNJEs, S. Pheochromocytoma. Am. J. Card. 9: 120 (1962).

13. Harrison, T.S., Dagher, F.J., Beck, L. \& BartLETT, J.D. Rationale and indications for preoperative adrenergic receptor blockade in pheochromocytoma. Med. Clin. N. Am. 53: 1349 (1969).

14. Clarke, A.D., Tobias, M.A. \& Challen, P.D. The use of neuroeptanalgesia during surgery for pheochromocytoma, Report of two cases. Brit. J. anaesth. 44: 1093 (1972).

15. Whitwam, J.G. \& Russell, W.J. The acute cardiovascular changes and adrenergic blockade by droperidol in man. Brit. J Anaesth. 43: 581 (1971).

16. LONG, G., Dripps, R.D. \& Price, H.L. Measurement of antiarrhythmic potency of drugs in man. Anesthesiology 28: 318 (1967).

17. Sumikawa, K. \& Amakata, Y. The pressor effect of droperidol on a patient with pheochromocytoma. Anesthesiology 46: 359 (1977).

18. BitTAR, D.A. Innovar-induced hypertensive crises in patients with pheochromocytoma. Anesthesiology 50: 366 (1979).

RÉSUMÉ

On doit tenir compte de plusieurs facteurs lorsqu'il faut administrer un myorésolutif pour l'anesthésie du malade porteur de phéochromocytome. On a prétendu que le pancuronium pouvait ètre le myorésolutif de choix. Cette observation décrit une crise hypertensive grave associée au pancuronium survenue chez un patient pendant l'exérèse d'un phéochromocytome. 